\title{
Challenges in Upholding Edutourism Initiatives
}

\author{
Herwina Rosnan ${ }^{1}$, Nuraisyah Chua Abdullah ${ }^{2}$ \\ ${ }^{1}$ Arshad Ayub Graduate Business School, Universiti Teknologi MARA, Malaysia \\ ${ }^{2}$ Faculty of Law, Universiti Teknologi MARA, Malaysia \\ herwinaros@gmail.com,nuraisyahc@yahoo.com
}

\begin{abstract}
Edutourism was initiated to benefit from both the booming tourism industry and the growth of education sector in Malaysia. Edutourism is expected affect related sectors positively. However, edutourism activities suffers from various challenges. The study investigates the challenges and barrier faced by public universities in realising edutourism agenda. Primary data was collected through interviews with selected public universities. Among the factors that hinders the development of edutourism are unsuccessful collaboration between university and travel agency as well as university readiness in upholding edutourism agenda. This study contributes to an in-depth understanding of the factors that impede edutourism success. Practical and theoretical implications were highlighted.
\end{abstract}

Keywords: Edutourism, Readiness; Malaysia; Public Universities

eISSN 2398-4295 @ 2018. The Authors. Published for AMER ABRA cE-Bs by e-International Publishing House, Ltd., UK. This is an open-access article under the CC BY-NC-ND license (http://creativecommons.org/licenses/bync-nd/4.0/). Peer-review under responsibility of AMER (Association of Malaysian Environment-Behaviour Researchers), ABRA (Association of Behavioural Researchers on Asians) and cE-Bs (Centre for EnvironmentBehaviour Studies), Faculty of Architecture, Planning \& Surveying, Universiti Teknologi MARA, Malaysia.

http://dx.doi.org/10.21834/ajbes.v3i14.161 
The term Edutourism is a combination of two words i.e. education and tourism. According to Ritchie (2003) edutourism refers to any tourism product offerings where participants travel to a destination with the primary objective to learn from that particular location.

Globalization and the liberalization of education sector escalates the growth of education market in Malaysia.The government of Malaysia is fully involved in the development of edutourism by implementing plans to position the country as regional hub for education and tourism. It has increased the number of universities as the government envisaged to turn the country into a global education hub. The government realizes that edutourism has huge potential to be developed as the country could benefit from both the booming tourism industry in Malaysia and the growth of education sector. In 2015, the government through the Ministry of Higher Education (MOHE) and the Ministry of Tourism and Culture (MOTAC) launched Malaysia 101 Edutourism Package. Among the objectives of edutourism are to mobilize public universities resources and to turn it into an income generation for the universities. Indeed, much has been done by MOTAC to facilitate the universities to develop tourism packages and encourage the local travel agents to participate with local universities in promoting the packages.

Edutourism is expected to affect related sectors positively. In the case of education sector, universities would benefit in terms of the creation of new source of income, the utilization of current facilities and expertise, the visibility of the universities and the proliferation of entrepreneurial effort among staff and students. Meanwhile, tourism sector will benefit through the participation of travel agencies in promoting attractive edutourism product offerings. Furthermore, edutourism has become an attractive business globally. However, despite the number of tour packages developed and effort towards promoting edutourism, tourists' acceptance and response on edutourism packages was not as expected.

\subsection{Tourism Industry in Malaysia}

The tourism industry has long been an important service sector in the Malaysian economy and has been identified as one of the major contributor to the gross domestic product (GDP) and economic growth (MIDA, 2017). According to United Nation World Tourism Organization (UNWTO) (2017) tourist arrivals has increased to 4 percent in 2016 from 25.7 million to 26.7 million. Globally, Malaysia remains one of the top-ranked tourists' destination. At present, the government of Malaysia continues its effort in ensuring increased number of tourists' arrival and the government has targeted an arrival of 36 million tourists by 2020 that would enable the country to generate an expected of RM103.6 billion in gross national income (GNP) for the country (Nair, Munikrishnan, Rajaratnam and King, 2015).

The development of tourism industry in Malaysia is a continuous effort made by the government since the 1990's where billions of ringgit has been invested for the development of this industry (Mosbah and Saleh, 2014). In a more recent development, a total of RM3.5 billion was announced under 2018 budget to boost the national tourism industry where up to RM2 billion is allocated for SMEs Tourism Fund (MHTC, 2017). An ongoing investment and development of tourism industry in Malaysia was translated in the increasing number of 
tourists' arrival with RM82.1 billion receipts in 2016 (Tourism Malaysia, 2017). Inconsistent with local data UNWTO reported that Malaysia's tourism industry yield per tourist is relatively low than that of the neighboring county like Singapore and Thailand based on 2016 data (UNWTO, 2017).

A more recent data from Economic Census 2016 indicates the total value added from tourism industry has increased by 10.3 percent from RM101.8 billion in 2010 to RM166 billion in 2015. Value added refers to the increment to the value of commodities and services contributed by the establishment where it is derived as the difference between the value of gross output and intermediate input (Economic Census, 2016).

\subsection{The Role of Travel Agencies}

Travel agents play an important role in country's tourism industry. In Malaysia, SMEs represent the majority of firms or travel agents in the tourism industry with up to 98.8 percent or 504,554 establishments. While large companies represent merely 1.2 percent or 6320 companies in 2015. Accordingly, SMEs were the larger contributor in the value added with RM115.6 billion as compared to large companies with RM50.4 billion in 2015. However, tourism SMEs value-added contribution if RM115.6 billion is relatively lower than the value added of other service sectors SMEs which is around RM179.6 billion in 2016 (Economic Census, 2016).

SMEs in tourism industry were usually started from entrepreneurship effort with limited resources and using their personal experience without any proper training (Zulkefli, Jaafar and Rashid, 2013). SMEs face challenges in terms of stiff competition within the industry, higher operating costs, lack of demand and unskilled employees. Since SMEs in tourism industry have limited resources, they can only offer rudimentary services, lack of various product packages offerings and use simple promotional activities in promoting their business. These shortcomings affect their competitiveness and performance as compared to larger travel agents in the tourism industry (Mohamad, 2016).

\subsection{Malaysian Education Sector}

From education sector perspective, developing countries play a significant role in the development of global education market where a strong pace of global education growth is witnessed. This is also the result of the increasing income of developing countries that enable more establishment of new institutions in higher learning. It is forecasted that the number of foreign students would increase from 1.8 million in 2007, to 7.2 million in 2025 in which India and China would contribute 70 percent of students (Bohm et al. 2002). Countries like Singapore and Malaysia would be an attractive location for higher education where international education is highly valued by candidates seeking a more affordable and cheaper education abroad. In countries where the cost of higher education has becoming expensive, it becomes a pushing factor for the students to study abroad. The increasing demand for tertiary education enable local higher institutions to allure a large number of international students. For developed countries, international education has been a promising export 
industry (Bhati, Lee and Kairon, 2014).

The term educational tourism or Edutourism refers to"an individual or group of individuals travel across international borders for the purpose of learning, or to engage in any form of knowledge acquisition." (Rodger, 1998). According to Abubakar, Shneikat and Oday (2014), "individuals who travel across international borders to acquire intellectual services are popularly known as educational tourist (edu-tourists). However, World Tourism Organization provides a more specific definition of edutourism as according to WTO (2012), edu-tourists are "individuals or groups who travel to and stay in places outside their usual environment for more than 24 hours and not more than one year"; with the motive to engage in learning, business, leisure and other activities. Previously, Ortiz, Chang and Fang (2015) forecasted that edutourism will attract $1,070,000$ students by 2017 . The authors also forecasted that the global spending on educational products and services is estimated to increase to $\$ 6.2$ trillion in 2017 from \$4.4 trillion in 2012 (Ortiz, Chang and Fang, 2015).

Many factors influence students to study abroad. Among other things are the use of English language as a medium of communication in most of higher learning institutions which open rooms for greater audience and candidate from all over the world. Other than that, university global ranking is an indication of a good place to study by international students where universities have increased their competitive advantage in education (Rico and Loredana, 2009). Globalisation also open rooms for candidate to venture into global new experience and global job prospect and career. Further liberalisation and free movement of factor of productions increase the opportunity for students to explore global opportunities, both in education and career. This phenomenon is further heightened where a new generation are willing and keen to leave their home country, and eager to travel and experience new cultures (Blight, 1995; Mansfield, 2013). Despite the prediction made by previous researchers, Smith and Jenner (1997) found that educational tourism has created little interest from the tourism industry and this is reflected in the gathering of research and data. In addition, Carr (2003) was in consensus with Smith and Jenner (1997) that empirically many areas have yet to be studied with reference to the associations between education and tourism. Furthermore, initial observation of educational tourism in Malaysia indicates little development of this sub-sector. Hence, the main aim of this paper is to investigate the challenges faced by local universities in upholding and sustaining edutourism projects. Subsequently, the study seeks to understand the challenges faced by the public universities in ensuring the success of edutourism initiatives.

\section{0 Literature Review}

There is an extensive scholarly discussion on educational tourism since the term was initially introduced. Educational tourism or edutourism is a sub-sector of tourism industry. Academics are particularly inclined on determining the factors that attract educational tourists. Edutourism has been seen as a new source of income generation for the country. In 1992, Kalinowski and Weiler took a major discussion of tourism research followed by the research work of Wood in 2001. At the beginning for the discussions, both scholars had focused their study and discussion on issues pertaining adult extension programs of adult tours and 
cultural educational tourism. In view of this, the Canadian Tourism Commission viewed educational tourism or learning tourism as "continuum ranging from general interest learning or exposure while travelling to purposeful learning and travel" (Ritchie, Carr and Cooper, 2003). The early discussion on educational tourism has shed new ideas and better understanding of the concept of education tourism. However, these researchers have contributed to a narrower scope of education tourism in that their concept of edutourism are more focused on the learning as the main objective, and travelling is expected to happened once students are in foreign countries and classify the students as edu-tourists. In the outset, the students' primary goals are to get a formal education and learning in the host country, and these students may be identified as education tourists even if they are not perceived to be tourists or if tourism is not their primary objective to come abroad. In brevity, the primary purpose of travelling abroad is for education, and during their tenure as students, they may have free time to visit in the host country and experience leisure activities. In this case, although these individuals may not see themselves as tourists, their behaviour can be associated with being tourists. Hence, this carries implication to the tourism industry in the host country even if their primary motivation were primarily on education.

Consistent with the previous study, Ritchie and his colleagues (2003) explained: "that educational tourism is basically about activity taken by those who are having an overnight stay and those who are undertaking an excursion as education and learning are primary or secondary part of their trip." The activities encompass all related educational tourism in general and adult study tours; this includes travelling by international university, domestic university and school students' travel, which also includes language schools, school excursions and exchange programs. Based on Ritchie et al. (2003) the definition of edutourism encompasses whether the educational tourism is independently or formally arranged which can be experienced in a variety of ways whether it is human-made settings or natural settings. An example of activities classified as edutourism includes a two-week visit to local homestay for the purpose of language-related learning and /or an academic exchange program between two schools and which travelling to local attractions become one of the activities in the itinerary (The Star, January 10, 2010).

Based on the Edutourism concept mentioned above, many universities and higher learning institutions are geared towards attracting international students and pursue an internationalisation strategy. Hence, most previous research have focused on understanding the push and pull factor to draw attention to attract and recruit international students. According to Felix and Steve (2007), pull elements include easy admission, international recognition and safe environment; and from the institutional perspective, the pull factors include course availability, expertise, cost of living, cheap accommodation and future employment prospects in the labour market. Whereas push factors subsume economic, political and host country capacity, which is contingent upon friends, family members, private agencies, media, and word-of-mouth (WOM) as noted by (Felix and Steve, 2007). A study by Mazarrol, Kemp and Savery (1997) has revealed that the countries' reputation and other universities' internal factors are important factors that influence the decision of international students to choose a place of study. The factors include quality of the education offered, marketing and promotional activities done by the universities, the profile of the academic 
staff, the program provided, universities academic collaborations with other agencies or fellow universities, and the sophistication of technological related culture of the university. For external factors, includes language factor (common language), historical links between the host country and the home country relationships, geographical proximity, and the availability of programs based on science and technology are the main factors for selecting a location to study. Lee and Tan (1984), identified political interest could be a significant effect that influences the decision to study abroad. A more recent study by Jason et al. (2011) identified financial assistance, attractive waiver of tuition fees and scholarship based on merit and other related aid to lessen the financial burden of students are also an interesting factor that could attract international students.

Most studies on edutourism emphasise on developing internal capacity to attract student to enrol. This findings is because they view foreign students will, by default, become a tourist. For example study by Ankomah and Larson (2004) highlighted problems facing edutourism in Sub-Saharan African attributed to inadequate financial resources to acquire necessary university equipment, lack of skilled staffs to deliver tourism instruction and image and reputation of the country. Similarly, study on edutourism by Lam, Ariffin and Ahmad (2011) highlighted institution image as a pull factor and job prospect as a push factor to allure candidates to study at Universiti Kebangsaan Malaysia.

The current study emphasise that market for edutourism products encompasses local and foreign tourists from various background as long as they want to come to university for experiential learning, formally or informally in university settings whether it involve natural or historical and multicultural university environment. Edutourism is also related to leisure and learning in an enjoyable university environment. Hence, this is the scope of edutourism concept of the current study.

\subsection{Methodology}

This study aims to investigate the challenges faced by local universities in Malaysia in upholding Edutourism projects. In order to achieve the objective of the study, a qualitative research design is the most appropriate approach. This study employs a qualitative research design which focus is not to produce "generalisability" of the findings but rather to gain understanding of the current phenomenon. The method used in the data collection in this study was through interviews, observation and the collection of secondary data. Using the constructivist paradigm as outlined by Piaget (2013), primary data was collected through interviews with the person-in-charge of Edutourism initiative in selected public universities. Sample size in qualitative research design is not statistically drawn. Hence, the selection of the sample is based on the lists provided by University Community Transformation Unit (UCTC), a unit Under Ministry of Higher Education Malaysia. These universities are identified by the Ministry to support national edutourism agenda.

The selections of the respondents are based on the willingness of the participant to participate in the study, and the criteria of the universities are based on those who faced difficulties in pursuing edutourism agenda. A number of 10 universities participated in this study. Informal interviews were conducted with representative from each universities. The 
interview sessions were recorded, and data were transcribe prior to data analysis. Analysis of the transcripts were done manually, looking at major ideas and views related to the objectives of the research. In addition, the transcripts were also compared to look at similarities and differences of the information gathered in which the conclusion were later drawn. Apart from that, a content analysis was carried out, and data from the analyses are presented descriptively. The study highlights the challenges faced by universities in carrying out edutourism initiatives.

\subsection{Results and Discussion}

Under current economic pressure, the national government is practising an austerity spending in which budget cut is affecting various ministries. Public universities are among government agencies which are affected by economic uncertainties. Hence, public universities cannot rely solely on government funding and must seek for an avenue to generate income to ensure university sustainability. Edutourism has been identified as one of the new sources of income generation by capitalising the facilities and expertise of the universities. Among the objectives of edutourism are to mobilise public universities resources and to turn it into an income generation for the universities. Indeed, much has been done by the Ministry of Tourism and Culture (MOTAC) to facilitate the universities to develop tourism packages and encourage the local travel agents to participate with local universities in promoting the packages.

This edutourism agenda would benefit particularly the university. It was also anticipated that edutourism would affect other sectors positively. In the case of universities, they would benefit in terms of the creation of a new source of income, the utilisation of current facilities and expertise, the visibility of the universities and the proliferation of entrepreneurial effort among staff and students. The travel agent would benefit from the attractive edutourism product offerings as globally, edutourism has become an attractive business.

The development of edutourism is a collaboration between three parties, namely, the university, the travel agency and the Ministry (MOTAC). Generally, the responsibilities of each parties are as follows:

Table 1: The role and responsibilities of related agencies

\begin{tabular}{|c|c|c|}
\hline University & Travel Agency & Ministry \\
\hline $\begin{array}{l}\text { - Identify products and develop } \\
\text { edutourism packages. } \\
\text { - Arrange for tourist guide at } \\
\text { campus. } \\
\text { - Manage and administer } \\
\text { bookings and bookings } \\
\text { confirmation. } \\
\text { - Establish a unit dedicated to } \\
\text { manage edutourism business } \\
\text { and manage payment. } \\
\text { - Ensure the safety of clients at } \\
\text { site. }\end{array}$ & $\begin{array}{l}\text { - Assist in the development of } \\
\text { edutourism package. } \\
\text { - Market and promote the } \\
\text { packages at local and } \\
\text { international market. } \\
\text { - Arrange out-camput tourist } \\
\text { guide and transportation. } \\
\text { - Arrange travel insurance. } \\
\text { - Manage payment by clients. } \\
\text { - Ensure payment is made to } \\
\text { university based on agreed } \\
\text { amount and terms. }\end{array}$ & $\begin{array}{l}\text { - An intermediary between } \\
\text { university and travel agency. } \\
\text { - Assist in product identification } \\
\text { at university. } \\
\text { - Collect and endorse university } \\
\text { edutourism product. } \\
\text { - Identify registered travel agent } \\
\text { to collaborate with the } \\
\text { university. } \\
\text { - Assist in preparing MoU } \\
\text { between university and travel } \\
\text { agency. }\end{array}$ \\
\hline
\end{tabular}




\begin{tabular}{|c|c|c|}
\hline $\begin{array}{l}\text { Support the promotion of the } \\
\text { products locally and } \\
\text { internationally. } \\
\text { Ensure bookings and payment } \\
\text { MUST be done through } \\
\text { registered travel agent. }\end{array}$ & - Submit sales report to MOTAC. & $\begin{array}{l}\text { - Conduct workshop for product } \\
\text { development. } \\
\text { - Promote packages at local and } \\
\text { international market. } \\
\text { - Monitoring. }\end{array}$ \\
\hline
\end{tabular}

(Source: MOTAC's slide presentation, 2015)

When edutourism was launched, it was targeting at over 5 million school children and more than 1 million university students locally. Market from abroad were not confined to university students but targeted at potential tourist who wish to participate in leisure and experiential learning activities. Product and packages were successfully developed. However, many issues cropped-up which cause the selling of packages almost impossible. Among the issues include collaborative agreement between university and travel agency, monetary issues, administrative issue etc.

Manoeuvring edutourism projects was not as easy as expected. The implementation of edutourism business model faced many unexpected challenges. To begin with, in most universities, edutourism is a project run by a group of individuals who are mostly academicians. Most of the academicians have little knowledge and experience in managing edutourism package. Despite the assistance from MOTAC to developed edutourism packages, lack of knowledge and experience in promoting and selling the packages deterred the effort. In the initial plan, universities were supposed to work with travel agencies where the task of promoting edutourism packages would fall under travel agent's responsibility. However, the university claimed that there are no indications that the packages were promoted judging from the response and feedback from the market. Besides, academicians' main duties at the universities are mainly teaching and learning. In some universities, academicians have to embark on research, consultations and hold administrative position. Juggling the work with a project is a daunting task for the academician. Priority should be given to the university's core business, i.e., teaching and learning. Furthermore, the profit margin of edutourism project is less lucrative as compared to embarking on research and consultation work. The motivations of the academicians are also a factor that contributes to the failure of edutourism agenda.

The study came into conclusion that human factor plays an important role. Indeed, major hindrance to edutourism is related to the readiness of academicians to be involved in edutourism projects as most of the people who participate in edutourism projects were mostly academicians who have to juggle between academic responsibilities and other activities. In addition, lack of incentives may also contribute to the academicians' behaviour towards edutourism projects.

Public universities' policies and its rigidity are among other factors exacerbate the efforts to develop a successful edutourism business. The findings also highlight the importance of top management support and acknowledgement in carrying out edutourism agenda.

The roles of travel agencies has also been put into question. It was found that most travel agent who engaged with the universities in the early establishment of edutourism projects are no longer in operations. This can be related to the size of the company in which most 
travel agents were small companies, and due to stiff competition in the tourism industry, many companies were not able to sustain the business. This finding is consistent with the previous finding which found that most travel agents in Malaysia are SMEs and SMEs are associated with lack of resources and using their personal experience without any proper training (Zulkefli, Jaafar and Rashid, 2013). SMEs face challenges regarding stiff competition within the industry, higher operating costs, lack of demand and unskilled employees. Since SMEs in the tourism industry have limited resources, they can only offer essential services, lack of variety product packages offerings and use simple promotional activities in promoting their business. These shortcomings affect their competitiveness and performance as compared to larger travel agents in the tourism industry (Mohamad, 2016). Furthermore, some travel agents lamented to university that selling edutourism package is not as lucrative as selling other outbound packages. Travel agents are also faced with difficulties to manoeuvre universities policies and procedures especially when it comes to money matters. These are the reasons why most travel agents withdraw from edutourism projects.

From the interviews, it was also found out that some of the universities received little support from other department and faculties to embark on the edutourism package. This is because edutourism products are products in the universities to be showcased, but there is no concerted effort by various departments and/or faculties to support this initiative. Policies and procedures are commonly challenging to be manoeuvred. For example, some tourist from foreign universities were interested in experiencing campus life and requested to participate in a real class setting. However, faculties were so tight up with classes and examinations and other academic activities that they refused to support this initiative.

Due to limited financial resources university was unable to establish a dedicated unit to manage edutourism activities. Governance and other related issues pertaining to the setting up of a special unit was difficult to be resolved. Issues like rental, payroll, utility bills requires strong justification and support from top management. Furthermore, in public universities, the process of setting up a business entity is challenging. In investigating the challenges in developing edutourism business, the data leads to the issue of readiness. Are the universities ready to embark on edutourism business? University internal engagement is one critical factor that could affect the realisation of edutourism agenda.

\subsection{Conclusion and Implications}

The study concludes that edutourism is indeed a promising project to be developed and a more robust business model is required to ensure success. Other public universities like Universiti Putra Malaysia has successfully established its edutourism centre. This study contributes to an in-depth understanding of the challenges in establishing edutourism business. The findings would lead to further improvement of edutourism initiates and efforts. This study also highlights the definition of edutourism that goes beyond merely enticing foreign students to register in local universities. This study takes a stance that special edutourism packaged developed by universities draws education tourists. Hence, foreign students studying in Malaysia are not, by default, an education tourist. This implicates future studies on establishing the definition of edutourism since many studies classified international students as education tourist. Future studies need to look further into this 
concept as the challenges in attracting international student to study locally are different with the challenges to attract tourists to experience edutourism products and packages.

This study contributes to knowledge and highlights the factors that hamper edutourism development. Practically, since university commonly lacks of financial resources to start income-generating project; a collaboration with industry or venture capital is an option. In addition, the realisation of edutourism agenda requires strong support from university' top management. A viable business model should be develop to get the support from the university as well as industry.

A sustainable edutourism should not be based solely on targeting at foreign tourists. The government through its agencies should revamp education policy to support national edutourism agenda. Primary and tertiary education should be required to incorporate edutourism programs in its curricula. Indeed, an exposure to university environment would create positive experience to school children. These students should be actively encouraged and required to participate in field trips to universities sites. Although currently, schools are organising field-trip, they seldom select university as their destination. By making it compulsory for schools to experienced edutourism products in one of their field-trip activities would directly contribute to a sustainable edutourism.

\section{Acknowledgement}

The authors would gratefully acknowledge the Institute of Research Management and Innovation (IRMI) Universiti Teknologi MARA (UiTM), Shah Alam and Ministry of Higher Education Malaysia (MOHE) for the financial support through the Fundamental Research Grant Scheme, File No: 600-IRMI/FRGS 55/3(36/2015).

\section{References}

Abubakar, A. M., Shneikat, B. H. T., \& Oday, A. (2014). Motivational factors for educational tourism: A case study in Northern Cyprus. Tourism Management Perspectives, 11, 58-62.

Ankomah, P. K., \& Larson, R. T. (2004). Education Tourism: A Strategy to Strategy to Sustainable Tourism Development in Sub-Saharan Africa. Retrieved April, 30(2009), 9-15.

Bailey, A. R., Chow, C. W., \& Haddad, K. M. (1999). Continuous improvement in business education: Insights from the for-profit sector and business school deans. Journal of education for business, 74(3), 165-180.

Bhati, A., Lee, D., \&Kairon, H. S. (2014). "Underlining Factors in Deciding to Pursue Australian Higher Education in Singapore"-An International Students' Perspective. Procedia-Social and Behavioral Sciences, 116, 1064-1067.

Blight, D. (1995), International Education: Australia's Potential Demand and Supply. IDP Education Australia, Canberra.

Carr, N. (2003). University \& college students' tourism. In: Ritchie, B. (Eds.), Managing educational tourism (pp. 181225). Clevedon, UK: Channel View Publications. 
Herwina Rosnan, H., \& Abdullah, N.C. / Asian Journal of Behavioural Studies (AjBeS), 3(14) Nov / Dec 2018 (p.1-12)

https://www.dosm.gov.my/v1/index.php?r=column/cone\&menu_id=UllyTnF2UTJMM1R1VmITTIZVbk5Wdz09

Fernandez, F. L. (1978).TeoríayTécnica del turismo.Tomo I. Madrid: Editorial Nacional.

Hassan, N. A., \&Hemdi, M. A. (2016). The Influence of Destination Image on Medical Tourist's Intention for Future Destination Choice. Environment-Behaviour Proceedings Journal, 1(1), 178-185.

Kalinowski, K., \&Weiler, B. (1992). Review educational travel. In: B. Weiker and C. Hall (Eds), Special Interest Tourism. London Belhaven.

Lam, J., Ariffin, A. A. M., \& Ahmad, A. H. (2011). Edutourism: exploring the push-pull factors in selecting a university. International Journal of Business \& Society, 12(1).

Lee, K. H., \& Tan, J. P. (1984). The international flow of third level lesser developed country students to developed countries: Determinants and implications. Higher education, 13(6), 687-707.

Maggi, R., \& Padurean, L. (2009). Higher tourism education in English-where and why?. Tourism Review, 64(1), 4858.

María Cubillo, J., Sánchez, J., \& Cerviño, J. (2006). International students' decision-making process. International Journal of Educational Management, 20(2), 101-115.

Maringe, F., \& Carter, S. (2007). International students' motivations for studying in UK HE: Insights into the choice and decision making of African students. International Journal of Educational Management, 21(6), 459-475.

Mazzarol, T., Kemp, S., and Savery, L. (1997). International Students Who Choose not to Study in Australia: An Examination of Taiwan and Indonesia. Australian International Education Foundation, Canberra.

Mohamad, A. A. A (2016). How can Small and Medium-sized hotels compete with international hotel chains? Egypt as a case study. Tourist Review International, 20(1), 57-70.

Mosbah, A. and Salleh, M. (2014). A review of tourism development in Malaysia. European Journal of Business and Management, 6(5), 1-9.

Nair, V., Munikrishnan, U. T., Rajaratnam, S. D., \& King, N. (2015). Redefining rural tourism in Malaysia: A conceptual perspective. Asia Pacific Journal of Tourism Research, 20(3), 314-337.

Ortiz, A., Li Chang, L. and Yuanyuan Fang, Y. (2015), International Student Mobility Trends 2015: An Economic Perspective.

Ritchie, B., Carr, N and Cooper, C. (2003) Managing Educational Tourism. Clevedon: Channel View Publications.

Rodger, D. (1998) Leisure, learning, and travel. Journal of Physical Education. Recreation \& Dance, 69(4), 28-31.

Smith, C., \& Jenner, P. (1997). Education tourism. Travel \& Tourism Analyst, 3,60- 75.

The Star. (2010). Edutourism gaining ground: South Koreans come to learn languages. 10 January, 27.

Wood, D. (2001). The winners and losers of participation in praxis: A case study of strategic tourism planning in Australia's North West. Paper for the World Planning Schools Congress, Shanghai, China, 11-15 July 2001.

UNWTO. (2017) UNWTO Tourism Highlight, 2017 Edition.

Zaman Yazarları (2014), "Zaman Yazarları", available at: zaman.com.tr (Accessed February 2016). 
Herwina Rosnan, H., \& Abdullah, N.C. / Asian Journal of Behavioural Studies (AjBeS), 3(14) Nov / Dec 2018 (p.1-12)

Zulkefli, N.S., Jaafar, M. and Rashid, M. (2013). Government role and Tourism-related micro and small business in the world archaeological heritage site of Lenggong Valley Malaysia, 